\title{
Jenny Lee : Keramikus Dan Pendidik Seni Keramik Di Surabaya
}

\author{
Belinda Dewi Regina \\ Jurusan Seni Budaya, S2 Pendidikan Seni Budaya, Universitas Negeri Surabaya \\ E-mail penulis : sofiamadiun@gmail.com
}

Jenny Lee merupakan keramikus perempuan sekaligus pendidik seni keramik yang berasal dari Surabaya. Jenny Lee sering mengikuti pameran tunggal maupun bersama. Keunikan dari karya keramik Jenny Lee adalah terletak dari konsep dan gaya keramik yang dimiliki. Kepandaian Jenny Lee dalam berkeramik menjadikan dia sebagai dosen DKV mata kuliah art and craft dan interior di Universitas Ciputra. Fokus penelitian ini (1) latar belakang kehidupan Jenny Lee sebagai keramikus dan pendidik seni keramik di Surabaya. (2) peran dan kontribusi Jenny Lee sebagai keramikus. (3) peran dan kontribusi Jenny Lee sebagai pendidik seni keramik. Tujuan penelitian ini untuk mendeskripsikan (1) latar belakang kehidupan Jenny Lee sebagai keramikus dan pendidik seni keramik di Surabaya. (2) peran dan kontribusi Jenny Lee sebagai keramikus. (3) peran dan kontribusi Jenny Lee sebagai pendidik seni keramik. Penelitian ini adalah penelitian kualitatif dengan pendekatan life history. Kajian teorinya menggunakan agen perubahan sosial. Lokasi penelitian ini di kediaman Jenny Lee tepatnya di daerah Kedurus gang IV/A, studio Keramik Jenny Lee tepatnya di jalan Laban Kulon gang 1 dan di Universitas Ciputra. Pengumpulan data ini melalui observasi, dokumentasi, wawancara. Temuan hasil penelitian ini berisi tentang kehidupan seorang Jenny Lee sebagai perempuan, keramikus dan pendidik seni keramik. Hal tersebut menjadikan ciri khas bagi Jenny Lee yang tidak dimiliki oleh seniman lain di Surabaya. Perempuan Tionghoa yang memiliki bakat berkeramik secara otodidak ini mampu membuat Jenny Lee dikenal sebagai salah satu seniman keramik di Indonesia yang menghasilkan karya-karya repro dengan mengkombinasikan budaya Indonesia dan Tionghoa. Teknik pembuatan keramik Jenny Lee menggunakan teknik pinch dan cetak sedangkan keeksistensian Jenny Lee sebagai seorang keramikus di Surabaya kurang begitu berkembang hingga akhirnya Jenny Lee memilih untuk menjadi seorang pendidik karena dengan mendidik akan mendapatkan income dan dapat mengenalkan serta menyalurkan bakat keramik yang dia miliki bagi masyarakat dan generasi muda yang membutuhkan referensi penelitian. Selain mendidik, Jenny Lee juga sebagai narasumber dalam workshop. Model pembelajaran Jenny Lee menggunakan pendekatan studio dengan mengajak mahasiswa untuk melakukan proses berkarya keramik dalam studio.

Kata kunci: Keramikus, Pendidik Seni Keramik

\section{Jenny Lee : Ceramics Maker and Educator in Ceramics in Surabaya}

Jenny Lee is a woman who works as Ceramics maker and ceramic art educators from Surabaya. Jenny Lee often follows the single or joint exhibitions. The uniqueness of her works is on her the concept and style. Her smartness in the making ceramics has made her a lecturer in DKV (Visual Communication Design) in the subject of art and craft and interior at the University of Ciputra. The focus of this research are (1) the background of Jenny Lee's life as a ceramics maker and ceramic art educator in Surabaya. (2) the role and contribution of Jenny Lee as a ceramic maker. (3) the role and contribution of Jenny Lee Ceramic as an Arts Educator. The purpose of this research is to describe and analyze (1) the background of Jenny Lee's life as a ceramics maker and ceramic art educator in Surabaya. (2) the role and contribution of Jenny Lee as a ceramic maker. (3) the role and contribution of Jenny Lee as a Ceramic Arts Educator. 
This research is a qualitative research with a life history approach. Research theories are biography and agents of social change. The research location is at the residence of Jenny Lee, in the alley Kedurus IV / A, Jenny Lee ceramics studio precisely at Laban Kulon street, alley 1 and at the University of Ciputra. Data collection is through observation, documentation, and interviews. The findings of this research is about the life of Jenny Lee as woman, ceramics maker and ceramic art educator. These make the uniqueness of Jenny Lee which are not shared by other artists in Surabaya. The Chinese woman who has a talent in making ceramics by autodidact learning who can make herself popular as a ceramic artist in Indonesia and produces repro works by combining the culture of Indonesia and Tionghoa. Jenny Lee's technique of making ceramic is a pinch and print technique but her existence as a ceramics maker in Surabaya is less developed until finally she decided to become a lecturer because by teaching she gets income and can introduce as well as deliver her talents in ceramics for the community and young people who need a reference for research. In addition to teaching, she also becomes a guest speaker for workshops. Jenny Lee's learning model is a studio approach by involving students to make the creation of ceramis in the studio.

Keywords: Ceramics maker, Educator in ceramics.

Proses Review : 19 April - 4 Mei 2017, Dinyatakan Lolos : 8 Mei 2017

\section{PENDAHULUAN}

Seni keramik di Surabaya kurang begitu berkembang, hal ini dibuktikan dengan sedikitnya seniman keramik yang ikut dalam setiap pameran yang diadakan di Surabaya. Namun di Surabaya muncullah keramikus perempuan bernama Jenny Lee yang masih eksis menggeluti bidang seni keramik sampai sekarang. Jenny Lee tidak hanya sebagai keramikus saja tetapi dia juga sebagai pendidik seni keramik yang berasal dari Surabaya. Jenny Lee telah mampu membangun sebuah atmosfer baru dalam upaya pengembangan seni keramik di Surabaya. Berbagai karya-karyanya hingga kini telah memberikan catatan penting terhadap laju perkembangan seni keramik di Surabaya. Jenny Lee menciptakan seni keramik karena awalnya dia tertarik setelah melihat karya keramik F Widayanto, dan akhirnya Jenny Lee mampu menciptakan karya keramik yang berbeda dengan seniman keramik lainnya. Di tengah-tengah masa studi D3 nya di ISI Yogjakarta, pada 2001-2004, Jenny Lee sudah getol berpameran. Setelah lulus dari kuliah D3 jurusan Kriya Cinderamata Keramik, Jenny Lee mulai mengadakan pameran tunggal di Via-Via Cafe, Jogyakarta sejak itulah nama Jenny Lee mulai dikenali masyarakat Yogyakarta kemudian kuliah S1 di Sekolah Tinggi Kesenian Wilwatikta Surabaya (2008-2009).
Jenny Lee memiliki keunikan dan kreativitas yang sangat menarik dari apa yang tidak dimiliki oleh orang lain. Keunikan Jenny Lee terletak dalam karyannya yang seringkali instalatif atau biasanya dalam jumlah cukup banyak. Selain itu Jenny Lee yang lahir dari keturunan Tionghoa selalu mengkombinasikan karyanya dengan budaya Indonesia. Jenny Lee sering mengadakan pameran baik itu tunggal maupun bersama, termasuk dalam pameran Biennale dan hanya Jenny Lee lah keramikus perempuan yang ikut dalam pameran Biennale tersebut. Selain mengikuti pameran, Jenny Lee Juga menjadi pengajar seni keramik di Sekolah Jepang Surabaya. Sebagai seorang pendidik Jenny Lee juga memberikan sumbangan pengetahuan dan pengalamannya yang berharga kepada anak didik serta masyarakat pecinta seni keramik untuk melestarikan, mengembangkan, dan memajukan seni keramik.

Jenny Lee juga bekerja sebagai dosen jurusan interior dan arts and crafts di Universitas Ciputra, diluar jam mengajar Jenny Lee seringkali mengisi acara workshop dan seminar. Karyanya yang repro dan memiliki ciri khas dengan mengangkat kehidupan sehari-hari di masyarakat seperti figure perempuan yang sedang berdoa membawa namanya melambung ke tingkat Nasional. Hingga akhirnya Jenny Lee diberikan kepercayaan untuk mendesain ruangan koleksi museum yang terletak di kota Roeun tepatnya di Normandia, utara Prancis. 
Dengan bakat yang dimiliki oleh Jenny membuatnya seringkali mengisi acara workshop dan seminar yang dilaksanakan di kota Surabaya maupun luar kota Surabaya.

Berdasarkan latar belakang masalah yang dikemukakan diatas, maka dapat dibuat rumusan masalah sebagai berikut:

1. Bagaimanakah latar belakang kehidupan Jenny Lee sebagai keramikus dan pendidik seni keramik di Surabaya?

2. Bagaimanakah peran dan kontribusi Jenny Lee sebagai keramikus?

3. Bagaimanakah peran dan kontribusi Jenny Lee sebagai pendidik seni keramik?

Berdasarkan rumusan masalah yang dikemukakan diatas, maka penelitian ini memiliki tujuan sebagai berikut:

1. Mendeskripsikan latar belakang kehidupan Jenny Lee sebagai keramikus dan pendidik seni keramik di Surabaya.

2. Mendeskripsikan peran dan kontribusi Jenny Lee sebagai keramikus.

3. Mendeskripsikan peran dan kontribusi Jenny Lee sebagai pendidik seni keramik.

\section{METODOLOGI}

Dalam penelitian ini menggambil lokasi di kediaman Jenny Lee sebagai keramikus dan pendidik seni keramik di Surabaya. Tepatnya di daerah Kedurus gang IV/A sebagai rumah pribadi Jenny Lee dan cara mencapai kediaman Jenny Lee tersebut yaitu dengan mengendarai kendaraan roda dua tepatnya di depan pabrik kaos Gawe Redjo dan bercat hijau serta dihiasi gambar daun-daun. Sedangkan alamat studio keramik Jenny Lee tepatnya di jalan Laban Kulon gang 1 sebelah rumah sakit Surya Medika. Selanjutnya penulis juga menggambil lokasi penelitian di Universitas Ciputra.

\section{Penyajian Data}

A. Latar Belakang Kehidupan Kreatifitas Jenny Lee sebagai Keramikus dan Pendidik Seni Keramik di Surabaya.

\section{Sebagai Keramikus}

Jenny Lee lahir di Surabaya pada tanggal 8 Maret 1976. Jenny Lee lahir dari keturunan tionghoa 8 Maret 1976. Perempuan keturunan Tionghoa ini berkecimpung di dunia seni karena dalam dirinya mengalir darah seni dari ayahnya yang pandai menggambar. Jenny Lee mulai terpikat dunia keramik saat menyaksikan pameran keramik karya $F$. Wijayanto. Jenny Lee pernah kuliah di jurusan selain keramik, namun pada akhirnya dia melanjutkan kuliah D3 di ISI Yogyakarta jurusan seni keramik, kemudian melanjutkan S1 di STKW Surabaya. Ditengah- tengah masa studinya, dia sudah ikut pameran diberbagai tempat baik pameran tunggal maupun bersama. Dengan karya repro kebanyakan berupa figur manusia yang mengangkat kehidupan sehari-hari di masyarakat sekitar serta kekhasan dalam karyanya yang mengkombinasikan budaya Indonesia dengan Tionghoa membuat nama Jenny Lee semakin dikenal, terlebih setelah mengadakan pameran tunggal di House Of Sampoerna serta satu satunya seniman keramik perempuan yang ikut dalam pameran Biennale yang hanya diadakan tiap tahun sekali.

\section{Sebagai Pendidik Seni Keramik di Surabaya}

Bakat berkeramik yang dimiliki oleh Jenny Lee menjadikan dia sebagai seorang pendidik. Jenny Lee menjadi seorang pendidik karena perkembangan seni keramik di Surabaya kurang begitu berkembang sehingga mengharuskan Jenny Lee untuk menjadi seorang pendidik seni keramik, Jenny Lee pertama kali mengajar di Sekolah Jepang Surabaya. Jenny Lee sampai sekarang sebagai dosen jurusan interior dan arts and crafts di Universitas Ciputra mulai tahun 2013. Jenny Lee sering mengadakan workshop maupun seminar, salah satunya sebagai pembicara dalam acara event Festival Seni Surabaya 2005. Jenny Lee juga pernah mengadakan workshop keramik dalam acara Bintang, Yayasan Pandita Sabha Buddha Dharma Indonesia.

\section{B. Peran dan Kontribusi Jenny Lee sebagai Keramikus}

\section{Membuka Studio}

Tahun 2008 Jenny Lee memiliki studio keramik bersama suaminya. Banyak mahasiswa yang berkunjung di studio milik Jenny Lee. Studio Jenny Lee juga dijadikan MES para mahasiswa untuk diskusi. Mereka sangat terbantu dengan adanya studio yang dijadikan MES tersebut. Tak jarang mahasiswa berkumpul hanya untuk melihat Jenny Lee berkarya. Pintu studi Jenny Lee dibuka lebar bagi mereka yang ingin belajar keramik. Jenny Lee memberikan pengaruh besar dalam seni keramik di Surabaya. 
Terkadang studio yang dimiliki Jenny Lee digunakan juga sebagai tempat pembakaran keramik bagi yang ingin membakar keramik. Tak jarang dari SMA di surabaya meminjam oven untuk membakar keramiknya namun mereka harus ketempat studio Jenny Lee. Melihat banyaknya antusias masyarakat untuk belajar keramik di studio Jenny, dia menambah satu oven lagi supaya lebih mudah dan tidak kerepotan. Secara tidak langsung mahasiswa maupun siswa Surabaya yang datang membuat keramik di Studio Jenny Lee akan mendapatkan inspirasi dari karya Jenny Lee bahkan akan mengembangkan gagasan dari karya Jenny Lee.

\section{Karya Jenny Lee sebagai Rujukan Siswa Untuk Berkarya Keramik}

Kepandaian dalam membuat karya keramik Jenny Lee sudah tidak diragukan lagi. Keikutsertaan dalam setiap acara pameran baik tunggal maupun bersama serta seringnya mengadakan workshop membuat perempuan ini banyak dikenali oleh masyarakat maupun seniman. Kecintaan Jenny Lee terhadap karya keramik membuat dia semakin giat dalam membuat keramik. Pengalaman pameran yang telah diikuti oleh Jenny Lee serta kepandaian dalam membuat keramik menjadikan dia sebagai bahan rujukan dalam berkarya keramik bagi pelajar. Melalui workshop banyak siswa yang ingin mencoba membuat karya seperti karya keramik Jenny Lee. Jenny Lee dijadikan bahan rujukan bagi kalangan pelajar maupun mahasiswa ataupun kalangan umum mencari Jenny Lee hanya untuk sebagai sumber dalam berkarya keramik.

\section{Karya Jenny Lee sebagai Alat Peraga dan Media Pembelajaran di IFI}

Sepulang dari Perancis, Institute Français Indonesia (IFI) mengajak seniman Agus Koecink dan Jenny Lee untuk memamerkan 25 karyanya, sebagai oleh-oleh selama residensi seni di Museum Sejarah Alam Rouen, Prancis. Jenny Lee menampilkan karya keramiknya di lantai dasar, dipajang puluhan keramik berbentuk burung berwarna merah muda. Burung-burung berwajah manusia itu diletakkan sesuai garis menyerupai rute jalan kota Rouen. Saat pameran di IFI terdapat hiasan keramik lain dengan konsep perpaduan Perancis dan Indonesia, misalnya saja, lima boneka dengan pakaian adat suku Normandi yang diletakkan dalam kotak berlapis kain batik. Juga empat perempuan Rouen yang dibentuk meyerupai boneka pewayangan, lengkap dengan pelepah pisang sebagai penyangga. Di IFI karya Jenny Lee menjadi alat peraga dan media pembelajaran oleh pusat belajar bahasa dan budaya Perancis. Mereka mencoba menjelaskan teknik yang dipakai oleh Jenny Lee saat pembelajaran berlangsung. Jenny Lee juga pernah memberikan workshop di IFI tentang bagaimana teknik mudah dalam berkarya keramik.

\section{Karya Jenny Lee sebagai Bahan Referansi Mahasiswa dan Penelitian Mahasiswa}

Karya-karya yang dimiliki oleh Jenny Lee sebagian banyak yang dijadikan bahan referensi oleh mahasiswa baik untuk tugas kuliah ataupun untuk penelitian. Studio yang dimiliki Jenny Lee seringkali digunakan untuk MES mahasiswa sebagai tempat diskusi. Banyak mahasiswa berkunjung tiap saat hanya untuk mendalami keramik Jenny Lee. Disana Jenny Lee selalu membuka pintu lebar bagi mahasiswa yang ingin belajar Keramik. Alat oven atau alat pembakaran Jenny Lee juga sering digunakan mahasiswa dari Universitas Ciputra untuk tugas kuliahnya. Karya-karya yang di simpan di studio Jenny Lee seringkali didokumentasikan oleh para mahasiswa untuk bahan referensi. Mahasiswa juga banyak yang meneliti karya Jenny Lee sebagai tugas penelitian mereka. Bagi mereka karya Jenny Lee merupakan karya yang unik sehingga ada juga yang menjadikan karya keramik Jenny Lee sebagai penelitian Skripsi maupun Tesis.

\section{Peran dan Kontribusi Jenny Lee sebagai Pendidik Seni Keramik \\ 1. Sebagai Pengajar}

Selain sebagai seniman yang berbakat dalam bidang keramik, Jenny Lee juga bekerja sebagai dosen jurusan "interior" dan "arts and crafts" di Universitas Ciputra mulai tahun 2013. Di Universitas Ciputra Jenny mengajar semester 1 sampai semester 6 . Sistem pembelajaran yang diajarkan oleh Jenny Lee berbeda dengan dosen seni kriya yang lainnya. Hal ini Jenny lakukan hanya ingin menularkan ilmu kepada mahasiswa Ciputra. Dia juga ingin mengembangkan bakat yang dimiliki. Kemenarikan dari model pembelajaran dari Jenny Lee yaitu Jenny Lee memberikan tugas kepada mahasiswanya untuk membuat karya sesuai dengan jurusan mereka masing masing, misalkan anak dari jurusan interior maka mereka membuat karya seperti lampion, asbak. Jenny Lee mengajarkan karya keramik terapan atau mempunyai fungsi dalam kehidupan 
sehari-hari seperti berbentuk lampion, asbak dan lainnya dengan tema budaya jawa.

Mahasiswa yang mengambil jurusan art and craft hasil karya mahasiswa Jenny Lee dihubungkan dengan fashion yang mengajarkan mereka membuat perhiasan yang mempunyai korelasi dengan jurusan mereka dengan material yang sama. Material yang dimaksud dalam hal ini sama-sama dengan keramik tapi bisa membuat kap lampu atau membuat perhiasan. Jenny Lee memberikan tema karya dari dua jurusan tersebut yaitu bertemakan batik Nusantara. Yang menarik dari Jenny Lee meskipun dia berasal dari tionghoa namun Jenny Lee lebih tertarik budaya Indonesia yaitu batik Nusantara dan wayang. Setelah mereka selesai membuat karya keramik, hasil dari karyanya mereka tampilkan dalam pameran mahasiswa di Ciputra sebagai tugas akhir. Dengan adanya hal tersebut menjadikan mereka lebih kreatif dan inovatif dalam berkarya.

Jenny mengajarkan bagaimana cara pembuatan keramik supaya lebih mudah dan tidak retak maupun pecah. Karena untuk menghasilkan produk seni keramik dibutuhkan rangkaian proses panjang. Proses dimulai dari mengenal jenis dan cara memproses tanah liat sebagai bahan baku, teknik pembuatan, pengetahuan glasir, hingga teknik pembakaran. Dalam berkarya, banyak mahasiswa menampilkan karya yang berbentuk botol kemudian dikombinasikan dengan bentuk wayang. Mereka membuat wayang Srikandi dengan alasan karena ingin melestarikan budaya yang ada di Indonesia. Semua anak masing-masing membuat karakter yang berbeda seperti wayang Srikandi dan Arjuna. Walau bentuk karya keramik mereka seperti botol maupun piring namun dengan mengusung tema seperti wayang menjadikan karya keramik berbeda dengan karya keramik lainnya.

\section{Narasumber Mahasiswa dan Masyarakat}

Jenny Lee sebagai seorang seniman keramik Surabaya sudah tidak bisa diragukan lagi kehebatannya dalam membuat karya keramik. Sebagaian besar dari karya-karya yang dimiliki oleh Jenny Lee dijadikan sebagai bahan referensi oleh mahasiswa baik untuk tugas kuliah maupun untuk penelitian. Dia juga sering menjadi narasumber untuk penelitian mahasiswa di daerah Surabaya karena bakat yang ingin mengetahui tentang sosok Jenny Lee dan karya keramiknya.
Karya-karya yang di simpan di studio Jenny Lee didokumentasikan oleh para mahasiswa untuk bahan referensi. Bagi mereka karya Jenny Lee merupakan karya yang unik sehingga ada juga yang menjadikan karya keramik Jenny Lee sebagai penelitian Skripsi maupun Tesis.

\section{Narasumber Workshop}

Sebagai pendidik dan seorang seniman, Jenny Lee juga sebagai narasumber dalam seminar maupun menjadi pelatih Workshop. Kepandaiannya dalam membuat keramik menjadikan Jenny Lee sebagai narasumber dalam Seminar. Banyak mahasiswa ataupun pelajar ingin berlatih teknik pembuatan karya keramik. Tak segan-segan mahasiswa menemui Jenny Lee di studio hanya untuk belajar keramik. Dia melatih para peserta workshop dengan penuh keuletan maupun ketlatenan. Para peserta sangat antusias dalam mendalami seni keramik. Mereka semangat melakukan tanya jawab langsung dengan seniman keramik. Dengan sabarnya Jenny Lee melatih dan memberikan ilmunya kepada para peserta Workshop.

\section{Perancang Media Pembelajaran IFI}

Sepulang dari Perancis, Institute Français Indonesia (IFI) mengajak pasangan seniman Agus Koecink dan Jenny Lee untuk memamerkan 25 karyanya, sebagai oleh-oleh selama residensi seni di Museum Sejarah Alam Rouen, Prancis. Jenny Lee menampilkan karya keramiknya di lantai dasar, dipajang puluhan keramik berbentuk burung berwarna merah muda. Burung-burung berwajah manusia itu diletakkan sesuai garis menyerupai rute jalan kota Rouen. Saat pameran di IFI Jenny menampilkan hiasan keramik dengan konsep perpaduan Perancis dan Indonesia. Misalnya saja, lima boneka dengan pakaian adat suku Normandi yang di letakkan dalam kotak berlapis kain batik. Juga empat perempuan Rouen yang dibentuk meyerupai boneka pewayangan, lengkap dengan pelepah pisang sebagai penyangga.

Karya Jenny Lee menjadi alat peraga dan media pembelajaran oleh pusat belajar bahasa dan budaya perancis di IFI. Mereka mencoba menjelaskan teknik yang dipakai oleh Jenny Lee saat pembelajaran berlangsung. Jenny Lee juga pernah memberikan workshop studio IFI tentang bagaimana teknik mudah dalam berkarya keramik. Jenny Lee membuatkan media pembelajaran berupa boneka- 
boneka, senjata dan ornamen khas Perancis untuk media pengenalan budaya Perancis bagi anak-anak yang datang kesana.

\section{Mengadakan Workshop Sekaligus Mengenal- kan Keramik Pada Anak Mulai Dini}

Sebagai pendidik dan seorang seniman, Jenny Lee juga sebagai narasumber dalam seminar maupun pelatih Workshop. Kepandaiannya dalam membuat keramik seringkali menjadikan Jenny Lee sebagai narasumber dalam Seminar. Banyak mahasiswa ataupun pelajar ingin berlatih bagaimana teknik dalam pembuatan karya keramik. Tak segan-segan mahasiswa seringkali menemui Jenny di studio hanya untuk belajar keramik. Seniman keramik ini melatih para peserta workshop dengan penuh keuletan maupun ketlatenan. Para peserta sangat antusias dalam mendalami seni keramik. Mereka semangat melakukan tanya jawab langsung dengan seniman keramik. Dengan sabarnya Jenny Lee melatih dan memberikan ilmunya kepada para peserta Workshop.

Jenny Lee tidak pernah memandang dari kalangan manapun yang ingin belajar keramik. Jika ingin belajar keramik Jenny Lee sangat senang dan berharap kedepannya banyak generasi penerus yang ingin mendalami karya keramik. Keramik baik.

\section{Mengajar Keramik di Sekolah}

Jenny Lee selain mengajar di Universitas Ciputra juga pernah mengajar di sekolah. Jenny Lee dalam mengajar hanya ketika ada sekolah yang mengundangnya sekedar untuk menjelaskan cara belajar keramik. Siswa sangat antusias dalam belajar keramik, menurut Jenny Lee melatih anak sekolah dengan mahasiswa memiliki kesan yang berbeda. Ketika mengajar siswa, Jenny lee harus ekstra sabar karena bagi mereka membuat keramik itu sedikit sulit.

Tak hanya siswa yang belajar keramik, ibu guru yang mengajar disekolah tersebut juga ikut belajar membuat keramik. Melihat keantusiasan mereka membuat Jenny Lee semakin sungguh-sungguh dalam mengajarkan keramik. Teknik yang diajarkan oleh Jenny Lee untuk para siswa berbeda dengan yang diajarkan para mahasiswa. Jenny Lee mengajarkan teknik pinch karena dirasa sangat mudah dan sederhana. Hanya dengan teknik pinch siswa sudah senang.

\section{Mengajar di Kampus Ciputra}

Jenny Lee juga bekerja sebagai dosen jurusan interior dan arts and crafts di Universitas Ciputra mulai tahun 2013. Di Universitas Ciputra Jenny mengajar semester 1 sampai semester 6. Sistem pembelajaran yang diajarkan oleh Jenny Lee berbeda dengan dosen seni kriya yang lainnya. Hal ini Jenny lakukan semata-mata ingin menularkan ilmu kepada mahasiswa Ciputra. Dia juga ingin mengembangkan bakat yang dimiliki. Yang menarik dari sistem pembelajaran yang diajarkan oleh Jenny Lee yaitu, Jenny Lee seringkali menghubungkan mata kuliah yang diajarkan dengan jurusan mahasiswa tersebut. Yang dimaksud dalam hal menghubungkan yaitu antara mata kuliah arts and crafts dengan jurusan mereka, misalkan anak dari jurusan interior maka daya mengajarnya, mereka membuat karya yang bisa mendukung wawasan mereka yang sesuai dengan jurusan yang dipilih. Jika dengan fashion Jenny Lee mengajarkan mereka membuat perhiasan yang mempunyai korelasi dengan jurusan mereka dengan material yang sama.

Material yang dimaksud dalam hal ini sama-sama dengan keramik tapi bisa membuat kap lampu atau membuat perhiasan. Jenny Lee memberikan tema karya dari dua jurusan tersebut yaitu bertemakan batik Nusantara. Yang menarik dari Jenny Lee meskipun dia berasal dari tionghoa namun Jenny Lee lebih tertarik budaya Indonesia yaitu batik Nusantara dan wayang. Setelah mereka selesai membuat karya keramik, hasil dari karyanya mereka tampilkan dalam pameran mahasiswa di Ciputra sebagai tugas akhir.

Mahasiswa seni kriya yang dipegang oleh Jenny diharuskan melihat karya keramik milik seniman keramik lainnya dan membuat kliping karya keramik untuk dibuat referensi mahasiawa dalam membuat konsep sesuai dengan gaya mereka masingmasing, meskipun awalnya banyak yang gagal namun dengan kegagalan mereka akan lebih banyak belajar dan lebih menguasai teknik yang diajarkan oleh Jenny. Dengan adanya hal tersebut menjadikan mereka lebih kreatif dan inovatif dalam berkarya.

\section{PEMBAHASAN}

\section{A. Jenny Lee sebagai Keramikus di Indonesia}

Setiap seniman dapat dikenal di masyarakat melalui 
karyanya yang memiliki kekhasan gaya, dan idenya yang menggugah nurani penikmat seni. Pada dasarnya memiliki fungsi entertain atau hiburan melalui nilai estetika yang terkandung di dalamnya. Lebih jauh seni berfungsi sebagai media sosial melalui sebuah gambar dan ekspresi seniman dalam upaya merespon berbagai aspek yang ada di lingkungannya melalui karya.

Jenny Lee merupakan salah satu bagian dari seniman keramikus di Indonesia. Kedudukan Jenny Lee sebagai seorang keramikus juga memiliki kekhasan dalam berkarya seni sehingga masyarakat mampu mengenalnya. Kekhasan karya seni Jenny Lee dari segi visual seringkali dibuat instalatif, dalam artian beberapa (biasanya dalam jumlah cukup banyak) figur dijejer sedemikian rupa untuk menghadirkan suasana atau gugahan tertentu dan merealisasikan konsep berkaryanya, sedangkan kekhasan dalam hal tema karya yaitu mengusung budaya Indonesia dan memasukkan sifat-sifat dan kegiatan perempuan dimana dia adalah seorang keturunan Tionghoa.

Keramikus perempuan yang memiliki bakat secara otodidak ini mampu membawa dirinya untuk berpameran tunggal pertama kali di kafe galeri Vi-Art, Jogjakarta. Tema pamerannya yaitu Saat Detak Detik Detak dengan menampilkan sekitar 20 karya keramik yang dimilikinya. Mulai dari tahun 2002 dalam Pameran Bersama 'Sepiring Indonesia'di Galeri Gelaran Yogyakarta sampai sekarang dalam pameran Biennale Jatim. Bahkan Jenny Lee juga pernah berpameran bersama Dona Prawita Arissuta.

Eksistensi Jenny Lee dibandingkan dengan keramikus lain di Indonesia berdasarkan bentuk dan konsep berkarya juga adanya kekhasan seorang seniman terlihat dari kedua indikator ini, keramikus tersebut antara lain: Hendrawan Rianto (Bandung), Suyatna (Jakarta), dan Noor Sudiyati dirujuk dari penelitian milik Endang Lestari yang berjudul: Eksplorasi Penciptaan Seni Keramik Kontemporer Indonesia. Analisis Terhadap Bentuk dan Konsep (Yogyakarta).

Keramikus pertama yaitu Hendrawan Riyanto (alm), dilahirkan di Yogyakarta sempat belajar seni dekorasi di Jepang pada tahun 1987. Semasa kuliah Ia memenangkan lomba kerajinan keramik se Jawa Barat. Karya Hendrawan mengarah pada seni murni dan tidak lagi memperlihatkan ciri-ciri keramik konvensional yang berbentuk wadah, tetapi lebih banyak berbicara masalah tentang konsep seni, tentang ekspresi dan komposisi seperti halnya seni patung, seni kontemporer dan totalitas. Jenis karya milik Hendrawan berbahan gerabah yang diikat dengan kawat yang ikut dibakar. Secara konsep karya-karya Hendrawan Riyanto, dia sering mengajak kita untuk kembali merenungkan tradisi dan nilai budaya timur. Namun dengan cara dan bahasa yang lebih puitis (Mulyadi, 2012).

Dibandingkan dengan Hendrawan Riyanto, seorang Jenny Lee dalam berkarya seni memiliki beberapa persamaan dan perbedaan, persamaannya yaitu sama-sama mengusung nilai budaya Timur, lebih spesifiknya Jenny Lee mengusung konsep budaya Indonesia secara jelas, seperti mengekspos batik sebagai ornamen dalam karyanya, mengekspose kebaya dalam bentuk karyanya yang icon-icon tersebut secara visual masyarakat di dunia pasti selalu menghubungkan dengan Indonesia. Bahan dasar yang digunakan Jenny Lee untuk membuat keramiknya yaitu stoneware berglasir, sedangkan dari segi bentuk Hendrawan Riyanto lebih menggunakan bentuk-bentuk simbolik lain seperti mencampurnya dengan bambu, berbentuk stupa stupa candi dan benda-benda lain khas Asia. Dalam konsep karya, Jenny Lee selalu mengusung tentang suasana kehidupan disekitar tempat tinggalnya dan kejadian-kejadian yang terjadi dan dialami oleh orang-orang disekitarnya terutama perempuan, terdapat sentuhan-sentuan feminisme dalam karya seni Jenny Lee sehingga budaya khas Indonesia dan jiwa seorang perempuan di diri Jenny Lee berkolaborasi dalam karyanya meskipun sama-sama diungkapkan secar puitis.

\section{B. Jenny Lee Sebagai Keramikus Perempuan di Surabaya}

Seorang Jenny Lee yang belajar seni keramik hingga menjadi seorang keramikus perempuan memperoleh pengetahuan keramiknya pertama kali secara otodidak, tidak mengherankan jika Jenny Lee serius dalam menciptakan karyanya. Ketertarikan Jenny Lee dalam dunia keramik hingga menjadi seorang keramikus perempuan ketika dia melihat pameran karya F. Widayanto. Semakin dia menemukan seseorang yang sejenis dengan dia seperti dia menemukan karya F. Widayanto maka semakin banyak ilmu yang dia serap. 
Selanjutnya jika Jenny Lee menemukan komunitas keramikus yang lebih banyak lagi maka dia akan memiliki kecenderungan menancapkan kukunya dan menyerap lebih banyak lagi ilmu untuk dijadikan inspirasi dan konsep karyanya.

Meskipun saat kuliah pernah tersasar jurusan, pada akhirnya Jenny Lee menemukan kecintaanya dalam dunia seni sehingga mendorongnya untuk mengambil keputusan kuliah di jurusan seni. Di tengahtengah masa studinya, Jenny Lee sudah getol berpameran baik pameran tunggal maupun pameran bersama dan saat merampungkan tugas akhir D3 nya Jenny Lee berpameran tunggal di kafe galeri Vi-Art, Jogjakarta. Pameran tersebut bertemakan Saat Detak Detik Detak dengan menampilkan sekitar 20 karya keramik.

Selain mengadakan pameran di Via Via Café, Jenny Lee juga pernah pameran di Visual Art Gallery pada tahun 2007 bersama Dona Prawita Arissuta dengan karyanya yang berjudul "Ngerumpi". Dalam karyanya yang berjudul "Ngerumpi"menggambarkan dua orang perempuan yang sedang bercakap dan menikmati keadaan sekitarnya. Jenny Lee menuangkan ide dan gagasan dari apa yang dilihat serta dialaminya. Setiap kali Jenny Lee berkarya, ide itu muncul dan divisualisasikan dalam bentuk karya keramik. Dalam pameran di Visual Art Gallery yang berjudul Ngerumpi ini figure perempuan digunakan Jenny Lee sebagai karya master sehingga memunculkan kecirikhasan Jenny Lee sebagai keramikus perempuan. Jiwa keperempuan Jenny Lee terlihat saat membentuk karya-karya keramik dengan figur-figur perempuan yang sangat luwes.

Setelah melanjutkan studi Sarjananya di STKW namanya semakin hari semakin dikenali masyarakat karena Jenny Lee sering mengikuti pameran bersama maupun tunggal di Surabaya. Kecintaannya sebagai seniman keramik membawanya untuk mengikuti pameran tunggal di House of Sampoerna mengusung 5 tema yaitu: Doa dari Perempuan, Khayalanku, Nikmatilah Hidupmu, Jangan Pernah Berhenti, My Diary. Dari ke 5 tema tersebut Jenny menampilkan karya repro yang berbeda dari seniman keramik pada umumnya. Kekhasan yang dimiliki Jenny Lee dalam hal tema karya yaitu mengusung budaya Indonesia dan memasukkan sifatsifat dan kegiatan perempuan dimana dia adalah seorang keturunan Tionghoa. Dia mengkombinasi kan karya keramik antara budaya Indonesia dengan budaya Cina.

\section{Jenny Lee Sebagai Pendidik Seni Keramik di Surabaya}

Jenny Lee juga melambungkan namanya lewat media keramik untuk membagikan ilmu kepada generasi penerus bangsa, dia melakukan itu untuk membuat perubahan yang signifikan terhadap perkembangan keramik dan memperkenalkan seni keramik melalui pendidikan seni. Dalam sudut pandang lain Herawati (1998:54), mengklasifikasikan fungsi pendidikan seni bagi perkembangan potensi kejiwaan anak menjadi tiga fungsi, yaitu: (1) bantuan seni bagi pertumbuhan dan perkembangan individu anak didik, dalam hal ini ketika Jenny Lee mengajar ilmu tentang keramik untuk siswa di sekolah Jepang dengan cara memberikan pengarahan seperti cara-cara dalam pembuatan keramik dan memberikan pelatihan supaya siswa dapat kreatif dalam berkarya, hal ini berarti sudah membantu perkembangan siswa dalam hal mengenal dan memahami karya seni keramik (2) bantuan seni bagi pembinaan estetik, artinya dengan menciptakan karya seni keramik mampu membangkitkan keindahan dalam diri siswa di Universitas Ciputra yang nantinya akan terwujud seni keramik yang sangat indah.

\section{SIMPULAN}

Berdasarkan hasil penelitian tentang "Jenny Lee : Keramikus dan Pendidik Seni Keramik di Surabaya" dapat disimpulkan beberapa hal yang juga menjadi jawaban atas pertanyaan dalam rumusan masalah dan akan dijabarkan sebagai berikut:

Latar belakang kehidupan Jenny Lee sebagai keramikus dan pendidik seni keramik di Surabaya dipengaruhi baik dari lingkungan keluarga maupun masyarakat. Perjalanan karier dan peran serta dalam dunia pendidikan tidak hanya sebatas menjadi dosen keramik namun Jenny Lee sering diundang untuk menjadi pembicara maupun tutor dalam workshop diberbagai kota. Peran dan kontribusi Jenny Lee dalam dunia pendidikan selain sebagai seniman keramik, Jenny Lee juga berperan sebagai pengajar di sekolah Jepang, narasumber mahasiswa dan masyarakat, narasumber workshop atau seminar, perancang media pembelajaran untuk IFI di Surabaya. 
Sedangkan kontribusinya membuka studio untuk mahasiswa di Surabaya, mengadakan workshop sekaligus mengenalkan keramik pada anak mulai dini, mengajar keramik di sekolah-sekolah, mengajar di kampus Ciputra dan membuka studio untuk umum. Sedangkan kontribusi lain Jenny Lee sebagai keramikus perempuan di Surabaya yaitu dengan ilmu dan karya keramik yang dimiliki Jenny Lee mampu mengajak perempuan lain untuk menjadi seorang keramikus di Surabaya. Dalam hal ini Jenny Lee bisa dikatakan sebagai pelopor keramikus perempuan di Surabaya. Jenny Lee juga mampu mengajak mahasiswa lain untuk menjadi generasi keramikus di Surabaya.

Penelitian ini mendapatkan temuan bahwa dapat diambil benang merah dari kehidupan seorang Jenny Lee antara perempuan, keramikus dan pendidik seni keramik itu memiliki keterkaitan seperti yang tergambar dibawah ini.

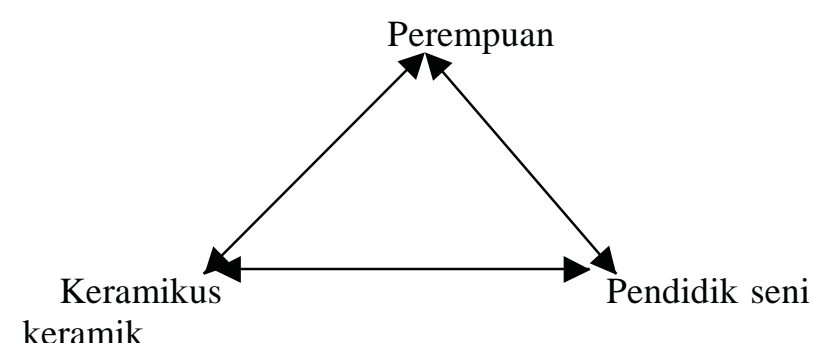
keramik

Perempuan Tionghoa yang memiliki bakat berkeramik secara otodidak ini merupakan perempunan yang tangguh dan eksistensinya dibangun sebagai seorang keramikus. Melihat perkembangan keramik di Surabaya kurang begitu berkembang, Jenny Lee justru menjadi seorang kreator yang lebih handal karena menurut Jenny Lee hal ini dapat diambil celah untuk eksis. Ketidak begitu berkembangnya seniman keramik di Surabaya menjadikan seorang Jenny Lee harus mencari penghasilan lain yaitu sebagai seorang pendidik. Dengan mendidik membuat Jenny Lee mendapat income (pendapatan tambahan).

Keunikan dia sebagai perempuan, keramikus serta pendidik seni keramik membuat Jenny Lee berbeda dengan perempuan lain yang ada di Surabaya. Seperti yang kita lihat kebanyakan dosen ataupun pendidik seni yang lain, mereka hanya bisa mendidik tanpa memiliki karya ataupun ikut berpameran. Kepandaian Jenny Lee dalam mengatur antara ibu rumah tangga, seniman keramik dan pendidik seni keramik mampu membuat Jenny Lee masuk dalam kategori perempuan keramikus yang masih eksis di Surabaya. Jenny Lee didalam mendidik bisa sebagai seniman dan sebagai seniman dia juga bisa mendidik.

Dengan memiliki dua kepribadian yang menyatu tersebut menjadikan Jenny Lee sebagai pendidik yang unggul. Jenny Lee dapat dijuluki guru yang seniman, seniman yang guru. Oleh karena itu apa yang menjadi ciri khas dari Jenny Lee sebagai keramikus sekaligus pendidik seniman keramik ini mampu menjadikan dunia seni khususnya keramik semakin berkembang. Berkeseniannya Jenny Lee sebagai seniman keramik mampu mendukung dia sebagai seorang pendidik atau sebaliknya. Jenny Lee juga eksis sebagai sebuah pribadi yang otonom, keotoritasan Jenny Lee sebagai seorang pendidik dan keramikus mampu membangun otoritas individunya, sehingga keeksistensinya sebagai otoritas individu itu mampu melepaskan dari mitos keperempuannya.

Eksistensi Jenny Lee sebagai seorang seniman dikuatkan dengan eksistensinya sebagai pendidik atau sebaliknya yaitu eksistensinya sebagai seorang pendidik dikuatkan dengan eksistensinya sebagai seniman. Sebagai pendidik, Jenny Lee mampu berpameran dan mampu membuat karya. Sebagai seniman, Jenny Lee juga mampu mendidik dengan baik. Dalam hal ini ilmu berkeramik yang dimiliki Jenny Lee sangat berpengaruh penting dalam mendidik.

\section{DAFTAR RUJUKAN}

Mulyadi, Agus. 2007. Wawasan Dan Tinjauan Seni Keramik. Denpasar : Paramita.

Herawati, Ida Siti dan Iriaji. 1998. Pendidikan Seni Rupa. Jakarta: Departemen Pendidikan dan kebudayaan Dirjen Pendidikan Tinggi. 